tão pura como antes, repetindo Costa Manso.

Faço-o com a consciência do dever cum prido, feliz por haver exercido a mais nobre das funçôes atribuídas ao homem e da qual sempre me orgulharei. E, reconhecido ao Senhor meu Deus, que me proporcionou tantas vitórias e a insigne glória, a mais honrosa a que possa aspirar um brasileiro, de concluir minha carreira de magistrado como juiz da Suprema Corte do Brasil." ${ }^{63}$

Da independência, da integridade, da imparcialidade, da discrição e da serenidade da magistratura do Ministro Thompson Flores, diz o caráter da trajetória que acabamos de apreciar, dinamizada, exclusivamente, pelos méritos pessoais.

Vestem-no sem folgas os versos de
Kipling, quando imagina um Homem que é capaz de não se corromper entre a plebe, de não perder a naturalidade entre os reis, de $s$ defender dos amigos, quer bons, quer maus, de ser sempre de alguma utilidade e de dar, a cada segundo do seu tempo, todo o valor e todo o brilho..

A aposentadoria, entretanto, não lhe foi o ponto final da atividade em prol do Direito daJustiça.

Dos pareceres que produziu, alguns se publicaram em revistas especializadas. ${ }^{64}$

A imagem do Ministro Carlos Thompson Flores permanecerá "aere perennius", evocando uma nobre existência e instigando as novas gerações de magistrados para a pugna sem desfalecimento em prol da Justiça.

\title{
Dignidade da pessoa humana: conceito fundamental do Direito Civil
}

\author{
Alexandre dos Santos Cunha*
}

"II n'existe pas de morale officielle." Bruno Oppetit **

"O absoluto, inclusive a busca do bèm absoluto, destrói a esfera pública pelo terror." Celso Lafer ***



INTRODUÇÃO

0

objetivo do presente trabalho é o de analisar o princípio da dignidade da pessoa humana como fundante do Direito privado, em especial no que tange às suas relações com a autonomia privada, apreciando ambos os institutos desde um ponto de vista histórico ${ }^{1}$, bem como a sua positivação e eficácia jurisprudencial.

Não é usual o tratamento de tal tema, geralmente relacionado com os direitos fundamentais, na área do Direito privado. No entanto, se operarmos na perspectiva de

* Mestrando em Direito Privado pela UFRGS. Professor de Teoria Geral do Direito Civil nas Faculdades Integradas Ritter dos Reis, RS.

** OPPETIT, Bruno. Philosophie du Droit, p. 137. ${ }^{* \star}$ LAFER, Celso. A reconstrução dos direitos humanos: um diálogo com o pensamento de Hanna Arendt, p. 270.

Segundo Emilio BETTI, em 'Storia e dogmatica del diritto", a análise histórica é fundamental para o tratamento dogmático de qualquerinstiutojurélico. 
RAISER $^{2}$, no sentido de superar a dicotomia, fundamentalmente ideológica, entre o Direito público e o Direito privado, tal ressalva carece de sentido. Além disso, conforme ressalta CAR VALHO, "se é inconcebível um Direito do Estado sem Estado, é igualmente inconcebivel um Direito Civil sem cives" ${ }^{3}$. Portanto, "é evidente que esse reconhecimento do homem como coração do Direito civil contemporâneo deve fazer do problema da proteção đos direitos do Homem (...) o problema central desse mesmo Direito civil"4

Desde esse ponto de vista, o tema ganha extrema relevância para os estudos de Direito privado, não só no que tange à autonomia privada, dogma civilístico, mas em especial em relação à pessoa, bem como às relações entre esta e aquela.

Assim sendo, partirei de uma análise do conceito de pessoa, em sua forma ideologizad pelo Iluminismo, o individuo, para, num segundo momento, apreciar a teia de direito formativos do conceito de dignidade humana as relações desta com a liberdade e a autonomia, e as supervenientes conseqüências.
- PESSOA E PERSONALIDADE DURANTE O PROCESSO CODIFICATÓRIO

Para compreender como o ser humano foi visto pela doutrina e tutelado pelas codificações oitocentistas, faz-se necessário o estudo da teoria das pessoas adotada por esses mesmos códigos, bem como da forma como essa foi cunhada, dentro de uma perspectiva Iluminista que MACPHERSON denomina de "individualismo possessivo"

Conforme ressalta MESSINETTI ${ }^{6}$, a teoria das pessoas tem a sua origem histórica na luta pela garantia da liberdade individual, possuindo a natureza de um privilégio concedido pelo soberano, ou seja, como diz STAMMLER? do fato de que ninguém pode depender integralmente do arbítrio subjetivo de outrem. Essa visão tem seu corolário em LOCKE: "a finalidade da Lei não é abolir ou restringir, mas preservar e aumentar a liberdade (...). Mas liberdade não é, como é dito, uma Liberdade para cada Homem fazer o que bem entenda: (...) Mas uma Liberdade para dispor, e regular, como entenda, sua Pessoa"8 Cf. Ludwig RAISER, Il compito del diritto privato. No mesmo sentido, ver também Daniela Silva Fontoura
de BARCELLOS, A descendência da dicotomia publicizacão do privado, privatizacão do público e a sua se BARCELLÇão: a perspectiva de Ludwig Raiser. Não trataremos da questão da positividade dos princípios jurílicos, superação: a perspectiva de Ludwig Raiser. Não trataremos da questâo da positividade dos principios juridicos, por considera-la superada, consistindo ordenamento jurídico em um sistema misto de principios e regras,
cf., entre outros, Claus-Wilhelm CANARIS, Pensamento sistemático e conceito de sistema na Ciência do Direito, $e$ Ronald DWORKIN, Taking rights seriously.

3 'S'il est inconcevable un droit de l'état sans état, il est également inconcevable un droit civil sans des 'cives' “ Orlando de CARVALHO, 'Les droits de l'homme dans le droit civil portugais", $p$. 6 .

4 "Il va de soi que cette reconnaissance de l'homme comme le coeur du droit civil contemporain doit faire du probleme de la protection des droits de l'homme (...) le problème central de ce même droit civil. "Orlando de CARVALHO, op. cit., p. 7.

${ }^{5}$ C. B. MACPHERSON, A teoria politica do individualismo possessivo de Hobbes a Locke.

6 Davide MESSINETTI, 'Personalità (diritti della)", p. 358

7 Apud Karl LARENZ, Derecho justo: fundamentos de ética jurídica, p. 58.

$s$ The end of Law is not to abolish or restrain, but to preserve and enlarge freedom (...). But freedom is not, as we are told, a Liberty for every Man to do what he lists: (...)But a Liberty to dispose, and order, as he lists, his Person. "John LOCKE, Two treatises of government, p. 306

Revista da Faculdade de Direito da UFRGS, v. 19, Março/2001
A emergência, no campo do Direito, do individualismo é fruto de um longo processo histórico que se inicia com a superação da prevalência, atribuída pelos gregos clássicos, da pólis sobre o individuo, basicamente por obra da filosofia estóica e cristã, para a qual a necessidade de salvação do indivíduo resultava numa maior valoração da vida contemplativa sobre a atividade política. Essa é a gênese da subjetivação moderna que reduziu a filosofia à epistemologia ${ }^{9}$, possibilitando, via nominalismo, a construção, por GRÓCIO, do conceito de direito subjetivo ${ }^{10}$. Nessas bases, afirma LAFER, "a passagem do Estado absolutista para o Estado de Direito transita pela preocupação do individualismo em estabelecer limites ao abuso do poder do todo em relação ao indivíduo" "11. Fechando essa visão filosófica, construirá KANT o conceito de sujeito de direito, que "é sempre o homem"12.

Foi essa concepção liberal-individualista da pessoa que possibilitou a construção dos direitos humanos, embora, conforme ressalta LAFER $^{13}$, também possa levar ao terror, como de fato ocorreu, durante a Revolução Francesa e em outras ocasiões, uma das quais terei oportunidade de sobre aqui discorrer.

Para tanto, iniciarei pela análise da teo-

ria das pessoas oitocentista, em especial de suas relações com a teoria do patrimônio de AUBRY ET RAU (1). Em um segundo momento, procurarei retratar a superação dessa concepção individualista de pessoa, a partir do desenvolvimento dos direitos fundamentais de segunda geração, e a conseqüente formação da teoria da personalidade (2). Concluindo o capítulo, apreciarei a posição do problema na doutrina brasileira de então, sobretudo o conceito de pessoa proposto por TEIXEIRA DE FREITAS no Esboço de Código Civil, por tudo o que encerra em si de inovador, ao mesmo tempo que retrato de sua época (3).

1. A teoria das pessoas e a teoria do patrimônio de AUBRY ET RAU

Consoante a tradição histórico-filosófica do conceito de sujeito de direito, afirma HATTENHAUER, categoricamente, que "o homem é o sujeito da norma jurídica e, conseqüentemente, único objeto da teoria da pessoa" ${ }^{14}$. É por isso que, para MESSINETTI, pessoa "não é um valor universal radicado na essência racional e imutável do homem, antes um valor real e objetivo, historicamente condicionado, de um determinado ordenamento positivơ" ${ }^{\prime 15}$.

9 A esse respeito, ver, entre outros, Celso LAFER, op. cit., pp. 118121.

10 Cf. Michel VILLEY, 'La genèse du droit subjectif chez Guillaume d'Occam ". A respeito, em especial sobre as relações do nominalismo com a filosofia do direito Iluminista, ver Gláucia Correa Retamozo Barcellos ALVES, Do nominalismo ao direito moderno: uma leitura de Michel Villey. Sobre as relasōes entre direito subjetivo, personalidade e patrimônio, ver Eroulths CORTIANO JÚNIOR, "Alouns apontamentos sobre os chamados direitos da personalidade", $p p .47-50$.

"Celso LAFER, op. cit., p. 122

12 T'est jamais que l'homme." Immanuel KANT, Métaphysique des moeurs, vol. 2, p. 269

Celso LAFER, op. cit., p. 130.

It El hombre es el sujeto de la norma jurídica y, consecuentemente, único objeto de la teooría de la persona." Hans HATTENHAUER, Conceptos fundamentales del Derecho civil, p. 14

15 'Non è un valore universale radicato nell'essenza razionale e immutabile dell'uomo, bensi un valore reale $\mathrm{e}$ oggettivo, storicamente condizionato, di un determinado ordinamento positivo." Davide MESSINETTI, op. cit., $p$ p. $355-356$

Revista da Faculdade de Direito da UFRGS, v. 19, Març/2001 
Tanto isso é claro que HATTENHAUER ${ }^{16}$ situa historicamente o surgimento desse conceito no pensamento de São TOMÁS DE AQUINO, e seu desenvolvimento da visão de homem como ser dotado de razão. Anteriormente, o Direito reconhecia a pessoalidade ${ }^{17}$ nas coisas. Tanto, na Idade Média, não era clara, como para nós o é, a relação entre pessoa e ser humano, que mesmo a idéia de que todos os seres humanos são pessoas foi apenas cunhada no século XVI, por obra do jusnaturalismo espanhol, em virtude da necessidade de auferi qual o status jurídico das populações indígenas nativas da América $^{18}$.

Indelevelmente ligados ao ser humano, os limites da pessoalidade são, portanto, o nascimento e a morte. Por isso, afirma OPPETIT, "sem ser estritamente sinônimo de pessoa, o corpo é, no entanto, conside rado como o suporte da personalidade do indivíduo" ${ }^{19}$. Dessa abstração advém que, embora prejudicados no uso de sua razão os loucos sejam pessoas.
Da submissão do conceito de pessoa ao de sujeito de direito resulta, contemporaneamente, que esse seja um conceito social, uma vez que só o homem em sociedade é dotado de direitos e deveres. Por isso CANOTILHO ${ }^{20}$ afirma a indispensabilidade de que todo o Estado de Direito tenha uma base antropológica estruturada constitucionalmente. Resultou também, quando da Escola histórica do Direito, em uma decadência dos estudos sobre a pessoa, em nome das teorias da capacidade jurídica, indispensáveis à teoria da relação jurídica ${ }^{21}$.

A restrição das preocupações dos juristas, no campo da pessoa, à capacidade jurídica, associada à visão individualista possessiva que levou MESSINETTI ${ }^{22}$ a cunhar o conceito de "lógica proprietária" para definir a metodologia civilística do século XIX, tem uma de suas mais amplas expressões na teoria do patrimônio desenvolvida por AUBRY ET RAU. Para esses autores, "a idéia de patrimônio deduz-se diretamen-
${ }^{16}$ Hans HATTENHAUER, op. cit., pp. 1415.

17 Cunhei, para este trabalho, o conceito de pessoalidade, relativo à teoria das pessoas, para contrapor, de forma clara, ao de personalidade, relativo à teoria da personalidade, embora se trate de um neologismo a priori gramaticalmente incorreto. Para as relaçóes entre pessoalidade e capacidade jurídica, ver Guido ALPA, Status e capacità: la costruzione giuridica delle differenze individuali, pp. 56-62

18 Cf. Hans HATTENHAUER, op. cit., loc. cit.

${ }^{19}$ 'Sans être strictement synonyme de la personne, le corps est néanmoins consideré comme le support de la personnalité de l'individu." Bruno OPPETTT, op. cit., p. 136.

2o J.J. Gomes CANOTILHO, Direito constitucional, p. 362.

${ }^{21}$ Cf. Hans HATTENHAUER, op. cit., pp. 18-19. O autor identifica tal opção como sendo reflexo das teorias de KANT e de SA VIGNY. A visão kantiana de que pessoa é o sujeito cujos atos podem ser-lhe imputados está na base do brocardo de SAVIGNY: toda relação jurídica é uma relação entre pessoas capazes.

22 Davide MESSINETTI, op. cit., pp. 356-357. Diz o autor que o Direito privado, no século XLX, via o "valor jurídico da pessoa como lógica proprietária. A validade teórica de uma tendência desse tipo, que faz do modelo proprietário, através do conceito de direito subjetivo, o esquema fundamental e unificador de todas modelo proprietário, através do conceito de direito subjetivo, o esquema fundamental e unificador de todas as possíveis manifestações do 'privado', no campo que a nós interessa, é legada por razões metodológicas e históricas bastante claramente identificáveis" "Valore giuridico della persona come logica proprietaria. La
validità teorica di una simile tendenza, che fa del modello proprietario, attraverso il concetto di diritto soggettivo, lo schema fondamentale e unificante di tutte le possibili manifestazioni del 'privato', nel campo che a noi interessa è legata a ragioni metodologiche e storiche abbastanza chiariamente identificabili.").

Revista da Faculdade de Direito da UFRGS, v. 19, Março/2001 te desta de personalidade. Qualquer que seja a variedade de objetos sobre os quais o homem possa ter direitos a exercer, qualquer que seja a diversidade de sua natureza constitutiva, esses objetos, enquanto formadores da matéria dos direitos de uma pessoa determinada, não são menos submissos ao livre arbítrio de uma só e mesma vontade, à ação de um mesmo poder jurídico; eles constituem, por isso mesmo, um todo jurídico (universum jus). ( ... ) Do patrimônio, sendo a emanação da personalidade, e a expressão do poder jurídico de que uma pessoa encontra-se revestida como tal, resulta: que apenas as pessoas fisicas ou morais podem ter um patrimônio; que toda pessoa tem necessariamente um patrimônio, mesmo que não possua atualmente nenhum bem; que a mesma pessoa não pode ter mais de um patrimônio, no sentido exato da palavra" ${ }^{\prime 2}$.

Foi tão forte a penetração da teoria cunhada por AUBRY ET RAU no pensamento civilístico oitocentista, que seus reflexos são visíveis ainda hoje. OPPETIT ressalta que esse é o grande entrave, na França, para uma compreensão correta e clara dos direitos da personalidade e das relações pessoais e patrimoniais, frente às novas necessidades do tráfego jurídico ${ }^{24}$.

A visão do patrimônio como corolário da personalidade, e não da pessoalidade, como seria o correto, é elementó fundamental para compreensão de como, a partir da teoria liberal da autodeterminação, construiu-se, no século XIX, aquilo que se chama ordinariamente de "império da autonomia da vontade"25.

Para o jusracionalismo jusnaturalista, as obrigações tinham seu fundamento no ato, vre manifestação do homem racional. A obrigação contratual, por exemplo, nascia do en contro de duas ou mais vontades. Essa doutrina tinha seu fundamento no fato de que, sendo o homem livre e racional, ninguém seria mais indicado para saber o que é bom para ele próprio.

Tal doutrina será superada por SAVIGNY, o qual sustentará a necessidade de previsão normativa para a constituição da obrigação. Os homens expressam sua vontade, a le obriga, a obrigação constituindo propriedade de uma parte contratante sobre uma parte da esfera de liberdade da outra, em direito subjetivo de uma sobre a outra. Uma vez que o patri-

${ }_{23}$ q'idée du patrimoine se déduit directement de celle de la personnalité. Quelle que soit la diversité de leur matière consitutive, ces objets, en tant que formant la matière des droits d'une personne determinée, n'en sont pas moins soumis au libre arbitre d' une seule et même volonté, à l' action d' un seul et même pouvoir juridique; ils constituent, par cela même, un tout juridique (universum jus). ( ... Le patrimoine étant une émanation de la personnalité, et l'expression de la puissance juridique dont une personne se trouve investie comme telle, il en résulte: que les personnes physiques ou morales peuvent seules avoir un patrimoine; que toute personne a nécessairement un patrimoine, alors même qu'elle ne posséderait actuellement aucun bien; que la même personne ne peut avoir qu'un seul patrimoine, dans le sens propre du mot ". AUBRYETRAU, Cours de Droit civil français d'après la méthode de Zachariae, tomo L, Pp. 333-336. Grifei. Comentand AUBRY ET RAU, dirá Miguel Maria de SERPA LOPES (Curso de Direito Civil, Vol. VI, pp. 62-63):


patrimônio a uma outra pessoa; a alienabilidade é restrita aos seus elementos constitutivos, pois o patrimônio,

Cf. Bruno OPPETTT, op. cit., p. 131. A respeito das implicaçôes filosóficas dessa teoria, ver René SEVE, "Détérminations philosophiques d'une théorie juridique: la théorie du patrimoine d'Aubry et Rau".

25 Cf. Alexandre dos Santos CUNHA, A autonomia privada frente à dicotomia público vs. privado: algumas reflexões. Essa visão diferenciada não exclui a possibilidade de patrimonialização dos direitos de personalidade, comum no mundo contemporâneo, e que pressupóe, no entanto, a diferenciação entre o campo da pessoa como processo, nota n. 175 . 
mônio, para AUBRY ET RAU, é composto desses mesmos direitos subjetivos, pode-se dizer inequivocamente, que, no terreno da livre von tade, o livre desenvolvimento da personalidade (pessoalidade) dá-se pela livre expansão do patrimônio: "ao concluir um contrato com outro, eu reconheço a autodeterminação do outro portanto o reconheço como pessoa" ${ }^{26}$. A esse respeito dirão AUBRY ET RAU:

"o patrimônio sendo, em sua mais alta expres são, a personalidade mesma do homem, considerada em suas relações com os objetos exteriores sobre os quais ele pode ou poderá ter direitos a exercer, compreende, não somente in actu os bens já adquiridos, mas ainda in potent os bens por adquirir. É o que exprime muito bem a palavra alemã Vermogen, que significa, ao mesmo tempo, 'poder'e 'patrimônio' O patr mônio de uma pessoa é o seu poder jurídico, considerado de uma maneira absoluta, e separado de todos os limites de tempo e de espaço' ${ }^{27}$.

Esse, o de tipo "lógico-proprietário", é o que MESSINETTI denomina como sendo o prmeiro modelo de pessoa: "a pessoa, em sua relevância 'sub specie iuris' de fato compreendida em sentido atomístico e pluralístico, como resultante de toda uma série de direitos expressamente reconhecidos pelo legislador para a tutela de interesses naturais da pessoa mesma mas especificamente individuada" ${ }^{28}$

Tal ponto de vista não pôde sobreviver, no entanto, à emergência social do final do século XIX. A massificação da atividade contratual acabou por impelir o legislador a limitar a autonomia enquanto, no campo político, surgiam os chamados direitos de segunda geração.

A convergência desses com as liberdades clássicas permitirá a LAFER identificar como estando na gênese da democracia no mundo contemporâneo. Cito: "entendo que esta desarmonia em relação ao papel do Estado na sociedade, na passagem da primeira para a segunda geração de direitos, obedece (...) na perspectiva 'ex parte populi', a uma dialética que pois as duas gerações de direitos baseiam-se na intuição da irredutibilidade do ser humano ao todo do seu meio social, e no pressuposto de que a sua dignidade se afirmará com a existência de mais liberdade e menos privilégios" 29 .

Como proteção do indivíduo frente ao nivelamento social da democracia de massas, ganha relevância no cenário jurídico a protecão da intimidade ${ }^{30}$ Sai de cena a teoria das pessoas. Começa a emergir a teoria da personalidade. subordina a contradição à complementaridade,

26 "Al concluir un contrato con otro, yo reconozco la autodeterminación del otro y por tanto le reconozco como persona." Karl LARENZ, op. cit., p. 65.

${ }_{27}$ Le patrimoine étant, dans as plus haute expression, la personnalité même de l'homme, considerée dans ses rapports avec les objets extérieurs sur lesquels il peut ou pourra avoir des droits à exercer, comprend, non seulement 'in actu' les biens déjà acquis, mais encore 'in potentią'les biens à acquérir. C'est ce qu'exprime très bien le mot allemand 'Vermogen', qui signifie tout à la fois, 'pouvoir' et 'patrimoine'. Le patrimoine d'une personne est sa puissance juridique, considerée d'une manière absolue, et dégagée de toutes limites de temps et d'espace". AUBRY ET RAU, op. cit., tomo LX, p. 334, nota n. 6. Grife.

28 'La persona, nella sua rilevanza 'sub specie iuris', viene intesa infatti in senso atomistico e pluralistico, come risultante cioè dei tutta una serie di diritti espressamente riconosciuti dal legislatore a tutela di interessi connaturati alla persona stessa, ma specificamente individuatti. " Davide MESSINETTI, op. cit., p. 356.

2 Celso LAFER, op. cit., p.130

3o Celso LAFER, op. cit., p. 263.

Revista da Faculdade de Direito da, LFRGS, v. 19, Março/200
2. Da teoria das pessoas à da personalidade

A visão reducionista do conceito de pessoa, operada pelo Direito oitocentista, fez com que o conceito perdesse totalmente o significado, tornando-se mera questão de técnica jurídca. A redescoberta da humanidadẻ desse conceito foi fruto de uma reflexão ética, impulsionada pela emergência dos direitos fundamentais de segunda geração, e pelo desenvolvimen to, pela pandectística tardia, do conceito de personalidade. Para HATTENHAUER, o direito de personalidade é "aquele que garante ao seu sujeito o domínio sobre um setor da própria esfera de personalidade. Com esse nome designam-se "os direitos da própria pessoa" 31 . Tratase de uma clara superposição do ético ao técnico, criando-se uma categoria, a da personalidade, que subordina a pessoa, e constitui direito subjetivo que deve ser respeitado por todos.

HATTENHAUER credita as origens da teoria aos juristas Georg Karl NEUER, Edouard HÖLDER e Otto VON GIERKE, este último o grande responsável por sua sistematizaçãa ${ }^{32}$. Ta teoria tinha a função de criar novas formas de tutela que suprissem as lacunas dos direitos fun- damentais do século XIX, como as relativas à honra, à intimidade, à saúde e integridade física e à vida privada. Embora seu desenvolvimento tenha-se dado anteriormente à elaboração do $\mathrm{BGB}^{33}$, a primeira expressão legislativa será 0 Código Civil suíço de 1907.

Orlando de CARVALHO ${ }^{34}$ vê, nos direitos de personalidade, três aspectos fundamentais: a essencialidade, a indissolubilidade e a ilimitabilidade, uma vez que o homem natura é, de per si, ilimitado. Assim sendo, a questão fundamental da teoria da personalidade é a do livre desenvolvimento e sua tutela: "para que cada um seja verdadeiramente uma pessoa, deve-se assegurar condições essenciais - condições essenciais para seu 'ser' e 'dever ser' às quais denominamos direitos de personalidade" ${ }^{35}$.

O conceito de personalidade e os direitos a ele relacionados é tão importante contemporaneamente, que $\mathrm{LAFER}^{36}$ identifica, amparado em ARENDT, uma esfera própria a ele relativa, com toda uma princi piologia própria. Se para a esfera pública o princípio fundamental é o da igualdade, enquanto na privada é o da diferença, sendo a esfera social a união de ambos, para a esfera da personalidade

${ }_{31}$ "Aquel que garantiza a su sujeto el dominio sobre un sector de la propria esfera de personalidad. Con ta nombre se designam "los derechos de la propria persona". Hans HATTENHAUER, op. cit., p. 23.

32 Hans HATTENHAUER, op. cit., pp. 22-24.

33 Para Orlando de CARVALHO, op. cit., p. 8, o BGB é um código anti-humanista, pois reduz o homem a mero elemento da relação jurídica. Não é de surpreender, portanto, que o capítulo do código destinado à pessoa não use, com exceşão do título, nenhuma vez a palavra. No entanto, Karl LARENZ, em seu Derecho civil: parte general, pp. 44-56, diz ser o personalismo ético kantiano uma das bases ideológicas fundamentais do BGB. Isso não desmente, porém, o jurista português. Afinal, a visão kantiana de personalismo ético diz muito mais respeito ao homem enquanto sujeito de direito, seus deveres jurídicos e a responsabilização, ou seja, a uma redução à pessoalidade, em detrimento da personalidade.

3* Orlando de CARVALHO, op. cit., pp. 9-11.

${ }^{35}$ Pour que chacun soit vraiment une personne, il faut qu'on lui assure des conditions essentielles - des conditions essentielles pour son 'être' et 'devenir' - , ce qu'on appele les droits de la personnalité." Orlando de CARVALHO, op. cit., p. 11.

${ }^{36}$ Celso LAFER, op. cit., pp. 267-268. 
vige o princípio da exclusividade ${ }^{37}$.

A visão personalista consiste, para MESSINETTI, um segundo modelo de pessoa: "em sentido global e unitário, como expressão das ações de todo o conjunto das leis positiva que têm como escopo a conservação e o desenvolvimento do sujeito, de um lado, e das intrínsecas potencialidades da pessoa emergentes do ordenamento, do outro"38.

A essas duas concepções divergentes de pessoa, opôs a doutrina brasileira, no século XIX através da obra codificatória de TEIXEIRA DE FREITAS, um terceiro modelo, bastante original, tanto no que guarda em si de superação permanência do pensamento individualista quanto no de premonitório em relação ao

3.A teoria das pessoas no direito privado brasileiro: o Esboço de TEIXEIRA

DE FREITAS e o Código Civil de 1916.

No ordenamento jurídico brasileiro, em codificatório, faz-se uma grande e desnecessária confusão entre os conceitos de pessoa e personalidade ${ }^{39}$. personalismo. É o que passo a analisar. especial pelas peculiaridades de nosso process

TEIXEIRA DE FREITAS, ao fundar o sistema de seu Esboço em uma rígida separação entre direitos pessoais e reais, na linha sugerida por $\mathrm{KANT}^{40}$, teve, necessariamente, de ser extremamente acurado quanto à sua conceituação de pessoa.

No Esboço, Seção I, Título I, estão reguladas as pessoas, definidas, no art. 16, como sendo "todos os entes suscetíveis de aquisição de direitos". No art. 17, separa TEIXEIRA DE FREITAS as pessoas em duas categorias:

"As pessoas ou são de existência visível, ou de existência tão-somente ideal. Elas podem adquirir os direitos que o presente Código regula, nos casos, e pelo modo, e forma, que no mesmo se determinar. Daí dimana sua capacidade, e incapacidade civil."

Aparentemente, TEIXEIRA DE TEITAS é um homem de seu tempo, e sua teoria das pessoas, embora acurada tecnicamente, não destoa da confusão oitocentista entre pessoalidade e personalidade ${ }^{41}$. No entanto, frizese, isso é apenas aparência. A separação entre direitos pessoais de relação civil e direitos pessoais de relação de família, exposta no art. 18 do Esboço, mostra claramente a visão diferenciada de nosso jurista: "Os direitos, que o presente Código regula, são considerados em relação ao

A respeito do principio da exclusividade, escreve Hannah ARENDT: "Aqui escolhemos aqueles com os quais desejamos passar nossas vidas, amigos pessoais a aqueles que amamos: e nossa escolha é guiada não por semelhanças ou qualidades compartilhadas por um grupo de pessoas - ela não é guiada, de fato, por por semelhanças ou qualidades compartihadas por um grupo de pessoas - ela não é guiada, de fato, por em sua singularidade, sua diferença em relação a todas pessoas que conhecemos". Apud Celso LAFER, op. cit., loc. cit.

3 'In senso globale e unitario, come espressione dell'azione di tutto l'insieme delle leggi positive che hanno come scopo la conservazione e lo sviluppo del soggetto, da una parte, e delle intrinseche potenzialità della persona emergenti nell'ordinamento, dall'altra ". Davide MESSINETTI, op. cit., $p$. 356 .

2 Para Clóvis BEVILÁQUA, inacreditavelmente, homem, pessoa e sujeito de direito deveriam ser tratados, pela legislacão civil, como sinônimos. É o que se pode inferir da seguinte passagem Em defeza do Projecto pela Codigo Civil brazileiro, p. 51): "É o homem, a pessoa, o sujeito de Direito que primeiro se deve destacar,

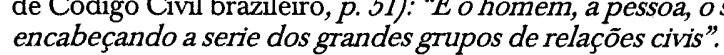

* Immanuel KANT, op. cit., pp. 69-75.

"I Sobre essa questäo, ver Alexandre dos Santos CUNHA, "A teoria das pessoas de Teixeira de Freitas entre individualismo e humanismo", no qual me detive mais longamente a respeito do tema.

Revista da Faculdade de Direito da UFRGS, v. 19, Març/2001 seu objeto, e distinguidos em direitos pessoais, $e$ direitos reais. Os direitos pessoais são distintamente considerados nas relações de família, nas relações civis."

Traça TEIXEIRA DE FREITAS, portanto, uma diferenciação clara entre o que denomina de direitos pessoais de relação civil, relativos ao patrimônio, e que podem, na perspectiva que construí a partir da teoria de AUBRY ET RAU, ser relacionados diretamente com campo da pessoa ${ }^{42}$, e direitos pessoais de relação de família, os quais dizem respeito ao campo da vida privada, e portanto, ao da persona lidade ${ }^{43}$. Nesse aspecto, como em outros, o Esboço demonstra ser bastante avançado em relação ao seu tempo.

A esse respeito, diz CORRÊA DE OL

VEIRA: "O primeiro grande mérito da grande construção de Freitas foi, sem dúvida, o tratamento por ele dado à distinção entre capacidade de direito e personalidade. Os dois conceitos andam em nosso século indesculpavelmente embaralhados pela doutrina brasileira. Essa distinção é fundamental, na medida em que a personalidade não admite gradações, admitindoas, porém, a capacidade de direito" ${ }^{44}$.

Semelhante confusão, na verdade, não é tão indesculpável. Advém, em grande parte, do fato de que o Código Civil de 1916, embora posterior ao desenvolvimento da teoria da personalidade, não tê-la incorporado, adotando a mesma estrutura anti-humanista do BGB, regredindo notavelmente em relação ao Esboço ${ }^{45}$. Nesse aspecto, emergem claramente aquelas que

42 E entre os quais poder-se-ia englobar, seguindo sistema do Esboço, os direitos patrimoniais de família, contidos na classificação do Projeto do novo Código Civil.

43 É notável o esforço depreendido por TELXEIRA DE FREITAS para, sem o amparo da então inexistente teoria da personalidade, sal var o humano frente ao técnico, desligando a possibilidade de a quisição de direitos da esfera puramente patrimonial, reconhecendo direitos não-patrimoniais, embora patrimonializáveis, típicos da contemporânea compreensão da teoria da personalidade. Vejamos a nota que escreve ao art. 21 do Esboço, referente à capacidade jurídica: "Não se entenda esta expressão no mesmo sentido, em que emprega Savigny. Para este escritor, que generalizara o Direito Romano, a capacidade de direito é, e não podia deixar de ser, o caráter distintivo dos seres humanos que aquele Direito reputava pessoas, por contraposiçâo aos que privava de personalidade. Para nós, para a civilização atual, todo o homem é pessoa: pois que não há homem sem a suscetibilidade de adquirir direitos, suscetibilidade que não chamo capacidade de direito tratando-se de pessoas, porque só o seria em relação a entes que não são pessoas. Quem, para distinguir a pessoa do que não é pessoa, empregar a expressão - capacidade de direito - capacidade jurídica como fazem os escritores de Direito Natural, confundir-se-á a si mesmo e aos outros; e, ou cairá na teoria do status e capitis diminutio do Direito Romano, ou nâo terá terminologia própria para exprimir a capacidade de direito das legislações modemas. Sabe-se que neste Projeto prescindo da escravidão dos negros, reservada para um projeto especial de leit mas não se creia que terei de considerar os escravos como coisas. Por muitas pue sejam as restriç̃os, ainda lhes fica aptidão para adquirir direitos; e tanto basta para que sejam pessoas".

4ue sejam as restriçoes, ainda lhes fica aptidão para adquirir direitos; e tanto basta para que sejam pessoas" e permanência", $p$ 362 Embora crítico da confuño da doutrina brasileira a respeito, o autor, no entanto e permanência", p. 362 . Enborimonialidade como aspecto chave para a diferenciacáo entre direitos pessoais dele vitu, ao não faz: aquela entre capacidade civil e capacidade de direito.

${ }^{45}$ Nẫo se pode alegar, em defesa do Código Civil brasileiro, um pretenso desconhecimento da doutrina nacional em relação às recentes teorias da personalidade, que foram adotadas pelo Código Civil suíço de 1907. Clóvis BEVILÁQUA, op. cit., pp. 217 e ss., demonstra ter perfeito conhecimento dos trabalhos de elaboração do referido Código, inclusive no que tange ao conteúdo.

Revista da Faculdade de Direito da UFRGS, v. 19, Março/200 
GOMES $^{46}$ define como sendo as características fundamentais de nosso Código: o patrimonialismo, o patriarcalismo e a responsabilização.

II- A DIGNIDADE DA PESSOA HUMANA COMO PARADIGMA DO DIREITO PRIVADO E SUA INTERFACE COM O DIREITO PÚBLICO NA ERA DA SUPERAÇÃO DA DICOTOMIA

A partir do desenvolvimento da teoria da personalidade, abriu-se todo um novo campo para a expansão de demandas de tutela, bem como de formalização de direitos que a ela estariam relacionados. Essas demandas acabaram por alçar a dignidade humana, enquanto princípio-fonte da teia dos direitos de personalidade, à categoria de direito do Homem, consagrado, inclusive, no art. 1 da Declaração Universal dos Direitos do Homem da ONU. Isso é em parte conseqüência do fato de que, segundo CARVALHO $^{47}$, se hoje há um sentido e um futuro para a História, ele está no Homem, não o ideal, mas o de carne e osso, que se faz a si próprio em um processo dialético: o Homem como processo.

Para o mesmo autor ${ }^{48}$, os direitos humanos devem ser compreendidos dentro de um

${ }^{4}$ Orlando GOMES, "Raízes históricas e sociológicas do Código Civil brasileiro".

47 Cf. Orlando de CARVALHO, op. cit., p. 3.

ts Cf. Orlando de CARVALHO, op. cit., p. 5.

*3 Touvelle aliénation, et, certes, plus dangereuse et plus ambigüe que les autres." Orlando de CARVALHO, op. cit., p. 3. Por identifićar o mesmo perigo, Celso LAFER (op. cit., p. 124) prega uma fundamentação historicista dos direitos humanos, posição essa que adotamos.

\$) Pour en faire des notions propres à la rationalité juridique, deux pas sont nécessaires. (i) Tout d'abord, une fois accepté un certain droit de l'homme, il est nécessaire de le faire passer de son 'état brut', c'est-à-dire de son pur caractère de droit naturel, à un 'état net', c'est-à-dire lui fournir le plus haut degré de précision posible. ( ii) Ainsi precisé, et mis en rapport avec d'autres concepts juridiques, ce droit devient un élément d'unsyste. ( juridique, de eccon que, dans un juridique, de façon que, dans un second temps, il soit possible d'en tirer, par une voie rationelle, des conséquences pratiques. "Enrique P. HABA, "Droits de l'homme, libertés individuelles et rationalité juridique (quelques remarques méthodologiques)", p. 338.

Revista da Faculdade de Direito da UFRGS, v. 19, Março/2001 resultantes desses direitos fundamentais.

Tendo adentrado no campo dos direitos fundamentais, torna-se relevante para nosso tema o reconhecimento da eficácia horizontal desses direitos ${ }^{51}$, considerando que, como propõe CARVALHO, o Direito civil é o campo por excelência para a realização desses direitos, por ser o direito comum do homem comum ${ }^{52}$

Essa visão anti-dicotômica, de complementaridade entre o Direito público e o Direito privado, não pode, no entanto, ser compreendida como uma fusão da esfera pública com a privada. A inexistência de limites entre o público e o privado é característica básica do totalitarismo ${ }^{53}$, cujo combate foi a pedra de toque dos direitos humanos no pós-guerra ${ }^{54}$.

A partir de sua inclusão na Declaração Universal dos Direitos do Homem, o princípio da dignidade da pessoa humana foi positivado em vários ordenamentos jurídicos. Constitucionalmente, em países como Alemanha, Brasil, Espanha, Grécia e Portugal. Na França, a positivação deu-se através do acórdão $\mathrm{n}$ 94.343.344 D.C., do Conselho Constitucional, depreendido de bloco de constitucionalidad quando da apreciação da reforma do Código Civil com vistas à implantação de princípios reguladores da bioética, e publicado em $27.07 .1994^{55}$.

Foi, no entanto, na Alemanha, pátriamãe da teoria da personalidade, que o princí-

sl Cf., entre outros, Konrad HESSE, Derecho constitucional y derecho privado.

32 Cf. Orlando de CARVALHO, op. cit., p. 6.

3 Cf. Celso LAFER, op. cit., p. 246.

5* Cf. Marie-Luce PAVLA, "Le principe de la dignité de la personne humaine: un nouveau principe constitutionnel", p. 100

35 Cf. Dominique ROUSSEAU, Les libertés individuelles et le principe de la dignité de la personne humaine, p. 62.

${ }^{56}$ Cf. Hans HATTENHAUER, op. cit., pp. 26-28. Nâo se pode esquecer que o BGB serviu tão bem ao Reich e ao nazismo quanto vem servindo à democracia alemâ.

Cf. Orlando de CARVALHO, op. cit., $p .15$.

pio da dignidade humana teve mais amplo desenvolvimento teórico e jurisprudencial, fornecendo bases racionais sólidas para que dele possase retirar conseqüências. É o que passo a anali$\operatorname{sar}(1)$. Em seguida, apresentarei a posição adotada, frente ao princípio, pela doutrina e jurisprudência francesas, e os riscos que podem advir desse entendimento (2). Finalmente, verei qual contemporânea compreensão da questão na doutrina e legislação brasileiras (3).

1. Direito privado e direitos fundamentais na Alemanha: a Menschenwürde e o papel da freie Entfaltung der Persönlichkeit.

$\mathrm{O}$ imediato pós-guerra representou um período de mudança radical na doutrina alemã que, professando fé na democracia, buscou uma interpretação constitucionalista do Direito como m todo, visando construir anteparos a um possivel retorno do totalitarismo ${ }^{56}$

A Lei Fundamental de Bonn, enquanto expressão máxima dessa nova fé, consagrou a Menschenwürde, a dignidade da pessoa humana, como valor fundamental, e a freie Entfaltung der Persönlichkeit o livre desenvolvimento da personalidade, como o fim de toda a ordem jurídica ${ }^{57}$.

Foi HUBMANN quem, em sua obra $\mathrm{O}$ direito de personalidade, a partir da promulgação da Grundgesetz, retomou as idéias de VON GIERKE e desenvolveu uma nova

(a)

Revista da Faculdade de Direito da UFRGS, v. 19, Marco/200 
teoria geral da personalidade, fundamentada no preceito constitucional de seu livre desenvolvimento ${ }^{58}$.

A perspectiva constitucionalista dos direitos de personalidade tem, segundo CANOTILHO $^{59}$, um forte componente antropológico. Para esse autor, seriam cinco os elementos constitutivos da teia de direitos formativa da dignidade humana: (i ) a afirmação da integridade física e espiritual do homem como dimensão irrenunciável de sua individualidade autonomamente responsável; (ii) o livre desenvolvimento da personalidade; (iii) a libertação da angústia da existência ${ }^{60}$, mediante mecanismos de socialidade, dentre os quais se encontram a garantia de condições mínimas de subsistência e o direito ao trabalho; (iv) a garantia e a defesa da autonomia individual, através da vinculação dos poderes públicos ao Estado de Direito; e (v) a igualdade formal. Nessa perspectiva, vê-se que uma série de direitos fundamentais, de primeira, segunda e terceira geração, encontram-se subsumidos pela teia

de direitos formativa da dignidade humana, como é o caso da autonomia privada. Por isso, NEGREIROS ${ }^{61}$ vê, no moderno Estado constitucional de Direito, uma íntima relação entre a dignidade humana e a construção de uma sociedade solidária, por um lado, e o livre desenvolvimento da personalidade com o desenvolvimento econômico, por outro ${ }^{62}$. Neste sentido, também posiciona-se $\mathrm{REICH}^{63}$, ao relacionar o livre desenvolvimento da personalidade com a liberdade de iniciativa econômica e profissional.

No entanto, como ressalta MESSINETTI, a norma constitucional é apenas um instrumento de formalização de um valor, que deve, a partir dela, ser concretizado. Afinal, "os valores aos quais diz respeito toda a possibilidade de vida do homem desenvolvem-se de forma material e, por assim dizer, existencial, ou seja, em uma palavra, vivendo"64. Essa valoração, porém, deve ser sempre feita a partir de outros valores que compõem o sistema jurídico, e nunca pela sociedade, sob pena de vivermos uma ditadura da opinião pública ${ }^{65}$

3 Cf. Hans HATTENHAUER, op. cit., loc. cit.

sy J.J. Gomes CANOTIHHO, op. cit., p. 363.

क Inclusive, como ressalta Hannah ARENDT (apud Celso LAFER, op. cit., p. 239) o direito fundamental à vida privada e à intimidade, este último compreendido como sendo o direito de estar só consigo mesmo.

ot Teresa NEGREIROS, Fundamentos para uma interpretação constitucional do princípio da boa-fé, pp. 218 219.

(2) A questão da associação do livre desenvolvimento da personalidade com a liberdade econômica e profissional, embora indispensável, gera um paradoxo. Numa sociedade capitalista, em que há a alienação do trabalho como regra, esse integra o patrimônio do indivíduo, também dizendo respeito, portanto, enquanto direito de personalidade patrimonializado, ao campo da pessoalidade. $A$ esse respeito, ver André Rodrigues CORREA, op. cit., loc. cit. Em sentido contrário, ver Karl LARENZ, op. cit., pp. 407-408

a Norbert REICH, Mercado y Derecho, pp. 89 ess.

6t "Il valore al quale si ri portano tutte le possibilità di vita dell'uomo si svolge in forme materiali e, per così dire, esistenziali: cioè, in una parole, vivendo ". Davide MESSINETTI, op. cit., p.360. Essa posição não exclui o seu contrário. Se a personalidade desenvolve-se materialmente com o decurso da vida, pode-se, analogicamente, considerar que também pode se expressar pela morte voluntária. Assim sendo, a questão da recusa de tratamento médico também deve ser analisada desde o ponto de vista da dignidade humana.

${ }^{65}$ Essa afirmação é apenas aparentemente anti-democrática. A garantia da esfera de intimidade e vida privada, contra a tendência niveladora da moderna sociedade da informação, é valor essencial à democracia. Como ressalta Celso LAFER, mesmo os romanos não desconheciamo "privado como refigio necessário à participação na 'respublica' "(op. cit., p. 261).

Revista da Faculdade de Direito da UFRGS, v. 19, Março/2001
A jurisprudência constitucional alemã vem interpretando a dignidade humana como sendo, além de direito fundamental, programa constitucional e princípio de base do Estado de Direito. Já há decisões consagrando-o na proteção da igualdade jurídica e da identidade e integridade física e mental, além de princípio informador das regras processuais penais ${ }^{66}$.

2. A tutela da dignidade humana na jurisprudência francesa, em especial o Arrêt du lanceur de nains.

Da mesma forma que na Alemanha, também na França a dignidade humana surge plena de boas-intenções, compreendida como barreira ao totalitarismo. Segundo ROUSSEAU ${ }^{67}$, compõe o bloco de constitucionalidade do princípio, fundamentalmente, o preâmbulo ao preâmbulo da Constituição da Quarta República, um libelo anti-nazista.

Para a mesma autora, a dignidade humana é a garantidora da precedência da pessoa humana, que deve ser respeitada desde o início da vida; e da integridade e não-patrimonialidade do corpo humano ${ }^{68}$. Antes de ser alçado ao nível constitucional, pelo Conselho Constitucional, o princípio já havia sido reconhecido como constante do sistema interno ${ }^{69}$ do ordenamento jurídico francês por um acórdão da Corte de Cassação, que o havia identificado

como base de resolução de conflitos no campo da bioética. Com o tristemente célebre Arrêt du lanceur de nains, o "Acórdão do atirador de anões", da Câmara de Contencioso Administrativo do Conselho de Estado ${ }^{70}$, que será minuciosamente analisado, tornou-se o princípio da dignidade humana assente na jurisprudência de todos os tribunais superiores franceses.

Apesar de toda essa construção jurisprudencial, ainda não há acordo na doutrina francesa sobre se a dignidade humana é ou não um direito fundamental.

Para ROUSSEAU ${ }^{71}$, a dignidade humana é um princípio de inteligibilidade dos direitos fundamentais, não sendo, portanto, um deles. É o seu princípio fundante, que deles depende para a sua concretização.

Em sentido contrário, PAVIA ${ }^{72}$ defende que a dignidade é um direito fundamental, que, no entanto, é hierarquicamente superior aos demais, o que nega toda a contemporânea teoria dos direitos fundamentais, que não os escalona hierarquicamente. Para a autora, quando em choque com a dignidade, qualquer outro direito fundamental é afastado, não havendo aplicação do critério de proporcionalidade ${ }^{73}$.

Essa última posição torna-se clara quando analisamos o "Acórdão do atirador de anões". Em linhas gerais, o caso em tela pode

of Cf. Marie-Luce PAVIA, op. cit., p. 102

Dominique ROUSSEAU, op. cit., p. 63.

as Dominique ROUSSEAU, op. cit., p. 65.

a Emprega-se aqui a expressão "sistema interno" no sentido que lhe é proposto por Karl LARENZ, Metodología de la Ciencia del Derecho, pp. $465-482$.

to C. E. Ass., 27.10.1995. Disponivel na Internet, na íntegra, em www.travelnet.com.br.

7 Dominique ROUSSEAU, op. cit., pp. 6869.

72 Marie-Luce PAVIA, op. cit., p. 112.

73 Devo a Humberto Bergmann $A$ VILA, "A distinção entre princípios e regras e a redefinição do dever de proporcionalidade", a definiçâo de proporcionalidade como critério, e não como princípio, como costuma ser denominado. 
ser assim relatado: duas prefeituras departamentais francesas baixaram decretos proibindo a apresentação de um novo tipo de diversão pública, o qual constituía-se num jogo em que o público era convidado a atirar, utilizando-se de um canhão de pressão, um anão à distância. Aquele que conseguisse arremessá-lo a uma distância maior, ganhava o jogo. A motivação de ambos os decretos era a proteção da dignidade da pessoa do anão, que era tida por aviltada, e não no risco de vida que poderia representar, uma vez que todos os requisitos de segurança eram respeitados.

No entanto, os promotores do jogo, em litisconsórcio com o anão que nele atuava, buscaram, pela via do contencioso administrativo, a anulação dos decretos, com base na proteção do livre exercício profissional. Apesar de derrotados na primeira instância, que outorgou ao anão uma pensão mensal no valor do salário que recebia para partici par do espetáculo, como forma de compensar a proibição de sua atividade profissional, este recorreu ao Conselho de Estado. Fundamentava o pedido de revisão da sentença de primeiro grau no fato de que não desempenhava aquela profissão apenas pela necessidade financeira, mas porque gostava do que fazia e sua atividade era um instrumento de socialização. Ou seja, no direito ao livre desenvolvimento de sua personalidade.

No entanto, o Conselho de Estado confirmou a sentença de primeiro grau. Patrick FRYDMANN, commissaire du gouvernement, escreveu literalmente nos autos: "o respeito da dignidade humana, conceito absoluto que é, não poderia cercar-se de quaisquer concessões em função de apreciações subjetivas que cada um possa ter a seu próprio respeito. (...) Por sua natureza mesma, a dignidade da pessoa humana está fora do comércio"74.

Incensando esse acórdão, escreveu ROUSSEAU que "a pessoa humana é um princípio que escapa à vontade, à apreciação ou ao julgamento da pessoa hu mana" 75 e, indo mais além, que "a pessoa não é livre para apreciar o que é ou não é digno dela e para ela, (sendo) necessário que a definição de sua dignidade lhe seja dada desde o exterior por uma autoridade"76. E arremata: "o princípio da dignidade é, talvez, como a felicidade das pessoas: ele corre freqüentemente o risco de querer concretizar-se sem o seu concurso" $" 7$.

As afirmaçōes da jurista francesa lembram por sua sobreposição da comunidade, politicamente organizada através do Estado, à pessoa do indivíduo, Karl LARENZ. Refiro-me ao primeiro LARENZ, freqüentemente esquecido. Aquele que escreveu:

"Decisivo para a posição jurídica do indivíduo não é mais basicamente sua condição de ser pessoa, senão sua condição concreta de membro da comunidade";

"Quem está fora da comunidade não possui direitos, ele não é camarada ${ }^{78}$ em sentido

${ }^{74}$ 'Le respect de la dignité humaine, concept absolu s'il en est, ne saurait s'accomoder de quelconques concession en fonction des appréciations subjectives que chacun peut porter à son sujet. (...) De par as nature même, la en fonction des appréciations subjectives que chacun peut porter à son sujet. (...) De par as nature meeme,
dignité de la personne humaine est hors commerce". Apud Marie-Luce PA VIA, op. cit., p. 108. Grifei.

75 “La personne humaine est un princi pe qui échappe à la volonté, à l'appréciation ou au jugement de la personne "La personne humaine est un principe qui échappe à la volonté,

76 'La personne n'est pas libre d'apprécier ce qui est ou non digne d'elle et pour elle, il faut que la définition de as "La personne n'est pas libre d'apprécier ce qui est ou non digne d'elle et pour elle, il faut que la définition de dignité lui soit donnée de l'extérieur par une autorité". Dominique ROUSSEAU, op. cit., p. 68. Grifei.
77 "Mais le princi pe de dignité est, peutêtre, comme le bonheur des gens: il est souvent risqué de vouloir le faire "Mais le princi pe de dignité est, peutêtre, comme le bo

z Sobre a criação, pela teoria do Direito nacional-socialista, do conceito de "camarada", em substituiçẫo ao de Sobre a criação, pela teoria do Direito nacional-socialista,
pessoa, ver Hans HATTENHAUER, op. cit., pp. 24-26.

Revista da Faculdade de Direito da UFRGS, v. 19, Março/2001 jurídico. Todavia muitas vezes é, e pode, o reitos humanos: um diálogo com o pensaestrangetro, nacondiço de convidar colocado em várias relações jurídicas em situação de igualdade e a um camarada";

"Camarada, em sentido jurídico, é apena quem é camarada do povo: camarada do povo é apenas quem possui sangue alemão"79.

Portanto, o mínimo que se pode dizer desse ti po de posicionamento é que ele é totalitário, em uma de suas piores acepções possiveis: o nazismo ${ }^{80}$

Acusar a decisão do Conselho de Estado francês, e toda a doutrina que o ampara, de totalitarismo, é negar expressamente o seu fun damento de constitucionalidade, uma vez que a tutela da dignidade da pessoa humana, como vimos, surge, no ordenamento jurídico daquele país, como de resto em todos, justamente como instrumento posto pelo Direito com o escopo de proteger o indivíduo dos totalitarismos.

No entanto, amparo esse posicionamento em Celso LAFER, e sua notável análise do f nômeno totalitário, A reconstrução dos dimento de Hannah Arendt. Para LAFER

"o totalitarismo representa uma proposta de organização da sociedade que almeja a dominação total dos indivíduos. (...) Trata-se de um regime que não se confunde com a tirania, nem com o despotismo, nem com as diversas modalidades de autoritarismo, pois se esforça por eliminar, de maneira historicamente inédita, a própria espontaneidade

- a mais genérica e elementar manifestação da liberdade humana" ${ }^{81}$

O totalitarismo rompe, portanto, com a tradição, que tem sua origem na "invenção", pelo Iluminismo, dos direitos humanos, e busca negar o valor da pessoa humana como "valorfonte" da ordem jurídica ${ }^{82}$, fazendo com que os indivíduos tenham apenas deveres frente à comunidade, destruindo por completo a esfera privada $^{83}$.

Segundo LAFER ${ }^{84}$, o totalitarismo tem sua origem na emergência social do final do século XIX, "que diluiu a clássica distinção entre o público e o privado". Foi nesse contexto "que surgiu a descoberta e a posterior tutela, no

Karl LARENZ, "Rechtsperson und subjektives Recht. Zur Wandlung der Rechtsgrundbegriffe". A seleção dos trechos e a tradução devo ao Prof. MSc. Itiberê de Oliveira RODRIGUES, da Universidade Federal de Pelotas. Sobre a teoria jurídica nacional-socialista de Karl LARENZ, ver, entre outros, Massimo LA TORRE, Nostalgia for the homogeneous community: Karl Larenz and the national-socialist theory of contract.

so "A respeito do papel da autoridade exterior regrando o comportamento das massas, escreveu Adolf HITLER, em Minha Luta, p. 277: "Essa organização (da coletividade pelo Estado) não deve impedir que os valores individuais surjam no seio das massas, mas, ao contrário, por uma açấo consciente, deve promover essa evolução facilitando-a por todos os meios possíveis. Deve partir do princípio de que a prosperidade nunca é devida às massas, mas às cabeças criadoras, que, por isso, devem ser vistas como benfeitoras da espécie. Facilitar-lhes a mais vasta influência está no interesse da coletividade. Esse interesse nunca será atendido pela dominação das massas incapazes, mas unicamente pela direção das almas privilegiadas pela Natureza". Um intelectual não deve jamais desprezar a importancia do que escreve, de sua obra para uma sociedude, todas suas implicasỗes. A esse respeito, ver Adriana Rodriguez PERSICO: Intelectuales hoy: ni anfitriones n

${ }^{81}$ Celso LAFER, op. cit., p. 117.

C. Celso LAFER, op. cit., p. 133

${ }^{23}$ C. Celso LAFER, op. cit., p. 245.

st Cf. Celso LAFER, op. cit., p. 263. Grifei

Revista da Faculdade de Direito da UFRGS, v. 19, Março/200 
âmbito do privado, do valor da intimidade como a maneira de fugir do mundo para o interior da subjetividade, algo que não é um dado, mas um construído". A tutela da intimidade, que deu origem ao desenvolvimento de toda a teoria da personalidade, surge, portanto, "como reação ao conformismo nivelador da sociedade, que exige que seu membros se comportem como se fossem membros de uma grande família, com uma só opinião e um único interesse". Ou seja, como resposta ao conteúdo potencialmente totalitário do nivelamento social de uma democracia de massas.

O princípio básico dessa esfera, como vimos, é o da exclusividade. Como escreve Hannah ARENDT:

"O princípio da exclusividade briga com o conformismo social. Um casamento misto (...) é um desafio à sociedade, mas é uma escolha válida que significa que os cônjuges preferiram optar pela felicidade pessoal, com

base no princípio da exclusividade, relegando para segundo plano o ajustamento ao social. Têm, conseqüentemente, direito à sua intimidade, cabendo garantir a tutela do right to be let alone" ${ }^{\prime 85}$.

O right to be let alone, o direito de livre desenvolvimento da personalidade, isento de in erferencia dos julgamentos morais ${ }^{86}$, por parte da opina publica, ou de restrica o estatal, da opinião pública, ou de restrição estatal, é elemento constitutivo e essencial da dignidade humana, fundamento do Direito privado e do Estado de Direito. Não pode ser nunca relativizado, a não ser caso interfira diretamente em direitos de terceiros ${ }^{87}$, sob pena de, pela busca do bem absoluto, cairmos no terror. $\mathrm{Pa}$ rece-me ter sido exatamente esse o caso, quando do julgamento do Conselho de Estado.

Há, todavia, ainda duas outras linhas pelas quais seria possível condenar o posicionamento da jurisprudência francesa. A primeira seria a representada pela dialética concreta de Orlando de CARVALHO ${ }^{88}$. A segun-

${ }^{85}$ Hannah ARENDT, Reflections on Little-Rock, apud Celso LAFER, op. cit., p. 268.

a Diz Bruno OPPETTT, op. cit., pp. 137-138: "a interdição endereçada à moral de se imisqüir na esfera do jurídico foi reforçada, na época contemporânea, pela preocupação de abandonar, em nome da liberdade da pessoa, a aplicação da moral à apreciação de cada consciência individual. (...) Assistimos desde alguns anos pessoa, a aplicaçáo da moral a apreciação de cada consciência iñes de nossa época sob a forma da ética. No a um forte retorno da moral ao primeiro plano das preocupações de nossa época sob a forma da ética. No entanto, a ética não pretende nenhuma verdade absoluta, ela não julga a ação dos homens e dos grupos sociais através de um sistema de valores transcendentes, ela se quer amoral, crítica e nâo-normativa" ("Linterdiction adressée à la morale de s'immiscer dans la sphère du juridique a été renforcée, à l'époque contemporaine, par le souci d'abandonner, au nom de la liberté de la personne, l'application de la morale à l'appreciation de chaque conscience individuelle (...) On assiste depuis quelques années à un retour en force de la morale au premier lan des préoccupations de l'époque sous la forme de l'éthique. Certes, l'éthique ne prétend à aucune premier plan des proces verité absolue, elle n'entend pas juger l'action des hommes et des grupes socia ".

* Esse limite é expressamente proposto por Hannah ARENDT, apud Celso LAFER, op. cit., p. 268.

- Para Orlando de CARVALHO, op. cit., p. 8, não hástandard possivel para a dignidade, uma vez que ela não pode utapar

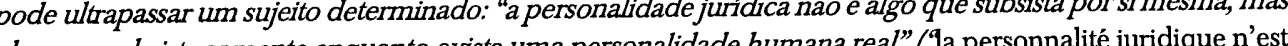
algo que subsiste somente enquanto exista uma personalidade humana real" "la personnalité juridique n'est pas quelque chose qui subsiste par soi même, mais quelque chose qui subsiste tant qu'il existe une personnalité humaine réelle."). Uma outra possível chave de leitura é a de que a dignidade da pessoa humana, enquanto princípio, é, no sentido hegeliano, um conceito geral concreto, enão um conceito geral abstrato.

Revista da Faculdade de Direito da UFRGS, v. 19, Marco/2001 da, a do racionalismo de $\mathrm{KANT}^{89}$, ou neokantiano, que identificamos em Léon $\operatorname{HUSSON}^{90}$. O que é difícil, efetivamente, é não condená-lo.

3. A dignidade humana e o ordenamento jurídico brasileiro contemporâneo: a CRFB-88, o chamado "Direito Civil Constitucional" e o Projeto do Novo Código, em especial a questão da disponibilidade do corpo humano.

Tendo analisado a tutela do princípio da dignidade da pessoa humana nos ordenamentos jurídicos alemão, cuja doutrina o desenvolveu, e francês, cujo exemplo nos alerta para os perigos de sua má utilização, resta discorrer sobre o tratamento a ele reservado no Brasil. Se está em vigor, hoje, um Código Civil que não contempla a tutela aos direitos da per-

sonalidade, a Constituição, como veremos, alça a dignidade humana ao centro do sistema jurídico, dando ensejo a uma ampla esfera de "direitos civis constitucionais" ${ }^{\prime 1}$. Da mesma forma, há uma série de leis esparsas que versam sobre o tema, como é o caso da Lei de Transplante de Órgãos (Lei federal n. 9434/97). Por outro lado, encontra-se em votação no Congresso Nacional o Projeto do novo Código Civil, de 1975, que busca dar um tratamento sistemático à questão. Assim sendo, apreciar-se-á, primeiramente, a situação atual do ordenamento jurídico brasileiro, para, num segundo momento, vermos como o Projeto propōe-se a sistematizá-la. Em um terceiro momento, utilizar-se-á a problemática da disponibilidade do corpo humano, uma das mais controversas questões atinentes à tutela da dignidade humana, para verificar-se qual o tratamento a ela reservado pela articulação entre a Constituição e o Código Civil e o que poderia mudar a partir da aprovação do Projeto.

Immanuel KANT, op. cit., p. 297, afirma que a consciência moral "não é dada (ao indivíduo) objetivamente pela razão teórica, mas unicamente de forma subjetiva pela razão prática, obrigando-se ela mesma a agir en conformidade consigo própria" "he lui est pas donnée objectivement par la raison théorique, mais uniquement de façon subjective par la raison pratique s'obligeant elle-même à agir conformément à elle ").

D) "O que confere direitos aos homens é, como proclama justamente a Declaração das Nações Unidas, que eles

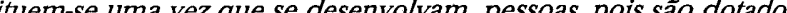
inteligência capaz de reflexan, que os toma aptos nono somente a estabelecerse fns, fomar projetos, descobrir ou inventar meios de realizá-los, mas tambem a tomar consciencia do seu ser, a interrogar-se sobr seu destino, e a conceber um ideal, bem como de uma vontade capaz de controlar seus impulsos e de regular seu comportamento transformando-o em conduta. Essas características conexas permitem-lhes assumir unilateralmente a responsabilidade de seu destino, o que lhes qualifica na linguagem fllosófica como pessoas. Éo respeito a essa personalidade que funda seus direitos" ("Ce qui confère des droits aux humains, c'est, comme le proclame justement la Déclaration des Nations Unies, qu'ils constituent, ou tout au moins sont appelés à devenr ense développant des personnes, parce qu'ils su'nt doués d'une intelligence capable de 作 les moyens de les réaliser, mais aussi à prendre conscience de leur être, à s'interroger sur leur destinée, et à concevoir un idéal, ainsi que d'une volonté capable de contrôler leurs impulsions et de régler leur comportemente en le transformant en conduite. Ces caractères connexes leur permettent d'assumer pour une part la responsabilité de leur destin, ce qui les fait qualifier dans le langage philosophique de personnes. C'est le respect de cette personnalité qui fonde leurs droits. "). Léon HUSSON, 'Droits de l'homme et droits subjectifs", p. 369 .

9l Embora encontre-se, hoje, espraiado pela doutrina, o termo "Direito civil constitucional" é de raríssima infelicidade, pois ninguém seria capaz de conceber um Direito civil inconstitucional. Por isso, preferimos considerá-lo como normas de Direito civil constantes do texto constitucional. 
A Constituição de 1988, já em seu artigo $1^{\circ}$, inciso III, eleva a dignidade da pessoa humana à condição de fundamento da Repúblca. O princípio, ali expresso, no entanto, informa todo o texto constitucional, emanando em uma série de outros dispositivos ${ }^{92}$.

É o caso da igualdade formal (art. $5^{\circ}$ inciso I), do direito geral de ação (art. $5^{\circ}$, inciso II), da liberdade religiosa (art. 5o, inciso IV), da liberdade de expressão (art. 5o, inciso IX), da intimidade, da vida privada, da honra e da imagem (art. 5o, inciso X), da inviolabilidade do domicílio (art. $5^{\circ}$, inciso XI), do sigilo de correspondência e comunicações (art. $5^{\circ}$, inciso XII) do livre exercício profissional (art. $5^{\circ}$, inciso XIII) do sigilo processual (art. 5o, inciso LX), dos direitos sociais do art. $6^{\circ}$, dos princípios gerais $d$ atividade econômica do art. 170, da usucapião constitucional dos arts. 183 e $191^{93}$, do direito saúde (art. 196), à educação (art. 205), à cultura (art. 215), ao desporto (art. 217) e a um meio ambiente ecologicamente equilibrado (art. 225) da proteção da família (arts. 226 a 230); e das tutelas da integridade física (art. $5^{\circ}$, inciso III) do dano moral e à imagem (art. $5^{\circ}$, inciso V). O Projeto do novo Código Civil dedica aos direitos da personalidade o capítulo II, título I, livro I da Parte Geral. O elemento articulado

do sistema, proposto pelo Projeto, é a cláusula geral do art. 11, que versa:

"Com exceção dos casos previstos em lei, os direitos da personalidade são intransmissíveis e irrenunciáveis, não podendo o seu exercício sofrer limitação voluntária" ${ }^{94}$.

Completa essa cláusula geral a do art. $12^{95}$, que dispõe sobre a reparação dos danos. Nos arts. 13 a 15, normatiza o Projeto a tutela à integridade física; nos arts. 16 a 19 o direito ao nome e sua utilização, e no art. 20 a preservação da imagem. Embora evoluindo em qualidade em relação ao Código em vigor, ganharia o Projeto se tivesse dado um tratamento em separado à patrimonialização dos direitos de personalidade, que é feito em conjunto, como no caso do art. 18, que dispõe sobre a cedência do nome próprio para fins de propaganda comercial. Essa melhor técnica legislativa facilitaria a articulação com a cláusula geral do art. 11, permitindo estabelecer claramente parâmetros gerais para a limitação voluntária dos direitos da personalidade.

Aliás, cabe discutir a constitucionalidade da irrenunciabilidade e intransmissibilidade do direitos de personalidade prevista no dispositivo s2 A jurisprudência do Supremo Tribunal Federal tem aplicado o princípio, como no caso do Habeas Corpus
n. 76060 SC, relatado pelo Ministro Sepúlveda Pertence, e que reconheceu ser inexigivel o constrangimento de réu à realização de exame de DNA, em processo de investigação de paternidade, por atentatório dignidade pessoal. In: DJ de 15.05.1998, p. 44.

93 A respeito das relações entre dignidade humana e teoria da posse, ver Laura Beck VARELA, Posse, conceito unitário, entre abstração e autonomia.

94 O alcance da cláusula geral aqui exposta foi bastante prejudicado pela adição ao Projeto, quando de sua primeira tramitação pela Câmara dos Deputados, da cláusula geral do art. 21, a partir de emenda do então deputado federal Tancredo Neves. Versa o dispositivo, à semelhança do Código Civil suíço de 1907, que "a vida privada da pessoa fisica é inviolável, e o juiz, a requerimento do interessado, adotará as providências necessárias para impedir ou fazer cessar ato contrário a esta norma". Enquanto o art 12 prevê a possibilidade de que o lesado, de mão própria, ou seja, sem a necessidade de recurso ao judiciário, interpele o agressor para fazer cessar o dano ao seu direito de personalidade, o art. 21 faz com que, no caso da tutela à vida privada, torne-se necessária a intervenção do judiciário.

95 Versa o texto: "Pode-se exigir que cesse a ameaça, ou a lesão, a direito da personalidade, e reclamar perdas e danos, sem prejuízo de outras sançôes previstas em lei".

Revista da Faculdade de Direito da UFRGS, v. 19, Marco/200

referido. Não colidiria essa previsão legislativa com o direito fundamental ao livre desenvolvimento da personalidade, nos casos em que patrimonialização do direito não ofendesse $d \mathrm{i}-$ reitos de terceiros? Ademais, essa é mais uma razão para que a reserva de um capítulo à questão da patrimonialização dos direitos da personalidade seja desejável.

Pode-se ter uma melhor visualização da implicações, no campo prático, da adoção de uma ou de outra posição a partir da análise de um dos mais controversos e importantes debates do Direito contemporâneo: a disponibilidade do corpo humano.

Conforme muito bem ressalta HERMITTE, hoje constituímos "uma sociedade que organiza de maneira racional o comér cio do corpo humano" ${ }^{96}$. Afinal, com o desenvolvimento da medicina, hoje tanto a transfusão de sangue quanto o transplante de órgãos são atividades cotidianas, e o Direito, à reboque da ciência, é chamado a regular uma série

\footnotetext{
Nous sommes amives à une societe qui organise de
}

de novas realidades: clonagem, barrigas de aluguel, destinação de embriões fertilizados in vitro e terapias gênicas. Frente aos fatos, o "constrangimento (da sociedade) vem mais da dificuldade de escapar à constatação final de que o corpo humano tornou-se, por motivos geralmente respeitáveis, uma matéria prima ou meio de produção" ${ }^{97}$.

Durante muito tempo ${ }^{98}$, buscou-se refrear a disponibilidade do corpo humano a partir do conceito de bem fora do comércio, embora isso constitua um verdadeiro absurdo. Segundo o art. 69 do Código Civil, "são coisas fora do comércio as insuscetíveis de apropriação, e as legalmente inalienáveis" ${ }^{\prime 99}$. Ora, se o corpo humano é inapropriável e inalienável enquanto totalidade, uma vez que isso seria permitir a escravidão, o que é inadmissível frente ao ordenamento jurídico, nada obsta a apropriação e alienaçãa ${ }^{100}$ de suas partes ${ }^{101}$. Muito antes pelo contrário: a doação de sangue e de órgãos é, inclusive, incentivada como um dever de solidariedade (CRFB, art. 199, § $\left.4^{\circ}\right)$, e, no

Nous sommes arrivés à une société qui organise de manière rationnelle le commerce du corps humain" Marie-Angèle HERMITTE, 'Le corps hors du commerce, hors du marché ", p. 323.

97 'La gêne venant plutôt de la difficulté d'échapper au constat final selon lequel le corps humain est devenu, pour de motifs généralement respectables, une matière première ou un outil de production”. Marie-Angèle HERMITTE, op. cit., loc. cit.

Segundo José Antônio Peres GEDIEL, em "Tecnociência, dissociação e patrimonialização jurídica do corpo humano", pp. 6465, essa tendência se afirma desde o século XLX. Para Marie-Angèle HERMTTTE, op. cit., p. 326, a primeira decisão nesse sentido foi prolatada pela Corte de Cassação francesa, em 27.06.1913. No entanto, ressalta a doutrina francesa rechaca esse entendimento desde pelo menos 1933 quando da publicasa conventions relatives à la personne physique” (op. cit., pp. 327 e ss.), persistindo, apenas, no que chama de "vulgata jurídica" (op. cit., p. 325).

o O Projeto do novo Código Civil, sabiamente, não traz um conceito de bem fora do comércio. Se algo é insuscetível de apropriação, é juridicamente irrelevante. Se tudo o que não é expressamente considerado pelo ordenamento jurídico como inalienável pode ser alienado, não há porque fazer constar isso do Código. O art. 69 é, por isso, perfeitamente inútil.

100 Define Augusto TELXEIRA DE FREITAS, emVocabulario Juridico, alienação como sendo "troca de título por causa", ou seja, a alienaçâo não tem, necessariamente, caráter oneroso.

${ }_{101}$ A esse respeito, diz Clóvis BEVILÁQUA, na suaTheoria Geral do Direito Civil, pp. 267-268: "Assim é que o homem tem a posse do proprio corpo, mas não póde validamente dispor de uma parte delle, (...) nem da propria vida. Póde, entretanto, alienar aquillo que deixou de ser parte de seu organismo vivo, como, por exemplo, os cabellos". Escrevendo bem antes da era dos transplantes, não podia nosso jurista pensar em exemplo menos singelo. 
último caso, obrigatória salvo disposição em contrário, por força da Lei federal n. 9434/97. Tornar o corpo humano indisponível equivaleria, por exemplo, a negar a legalidade da cirurgia plástica, uma vez que não se pode, no caso das intervenções cirúrgicas de finalidade exclusivamente estética, concluir por um "estado de necessidade" que justificasse a violação de um "direito-dever" à integridade física. Por isso, "mes mo que pudéssemos encontrar um princípio de indisponibilidade do corpo humano, é provável que ele não servisse de grande coisa" ${ }^{102}$ sendo um dado social, o Direito não pode negar a realidade.

Recentemente, como vimos na análise da jurisprudência francesa, tem-se buscado esse princípio de indisponibilidade do corpo humano na teia de direitos formativos da dignidade humana, uma vez que a integridade fisica é um dos mais importantes desses princípio. Conforme ressalta GEDIEL, referindo-se à tecnociência

"o acesso e o uso de dados genéticos humanos, para fins de pesquisa e aplicação terapêutica, exigem, portanto, a revisão preliminar dos conceitos jurídicos clássicos, pessoa, coisa e propriedade, cuja análise se radica na formação do Direito Moderno e compreende, também, as noçōes jurídicas de indissociabilidade entre o sujeito e seu corpo, garantia de dignidade essencial da pessoa humana e autonomia corporal" ${ }^{103}$.

A citação supra-referida chama a aten-

ção para um outro aspecto capital de nosso tema: a importância que teve a "lógica proprietária" na formação e na compreensão que os juristas têm da personalidade. Conforme ressalta MOULY, "o direito de propriedade foi (...) transposto das coisas (seu domínio natural) para as pessoas, para o seu estado civil, para a sua imagem, para as criações intelectuais" ${ }^{104}$. O que faz com que a superação do conceito clássico de propriedade, fundado sobre a propriedade fundiária, dando lugar à idéia de que existem múltiplos ti pos de propriedade ${ }^{105}$, a alteração daquilo que GROSSI 106 denomina como sendo a nossa "mentalidade proprietária", seja fundamental para uma correta compreensão das relações entre o homem e o seu corpo.

GEDIEL ressalta que existem três diferentes formas de ver essas relaçôes: a primeira delas considera homem e corpo como unidade indissociável; a segunda, tem o corpo como propriedade do sujeito; e a terceira corrobora essa relação de propriedade, considerando o corpo, no entanto, uma propriedade indisponivel $^{107}$. Consoante todo o exposto até agora, a primeira dessas correntes parece ser a mais razoável. O corpo humano, enquanto suporte da pessoa, não pode ser considerado como propriedade dela. Por isso, a esfera da personalidade é claramente extra-patrimonial, não podendo ser alvo de limitação por parte do Estado, somente de tutela, sob pena de estar comprometido o direito fundamental ao livre desenvolvimento da personalidade.

102 'Même si l'on avait pu trouver un principe d'indisponibilité du corps humain, il est probable qu'il n'aurait pas servi à grand chose". Marie-Angèle HERMITTE, op. cit., p. 324.

${ }^{103}$ José Antônio Peres GEDIEL, op. cit., p. 60.

${ }_{104}$ 'Le droit de propriété fut (...) transposé des choses (son domaine naturel) aux personnes, à leur état civil, à leur image, à leurs créations intellectuelles". Christian MOULY, "La propriété”, p. 475.

${ }_{105}$ Cf. Ana PRATA, A tutela constitucional da autonomia privada, p. 186.

${ }^{106}$ Cf. Paolo GROSSI, La propiedad y las propiedades: un analisis histórico, pp. 59 e ss.

${ }_{107}$ José Antônio Peres GEDIEL, op. cit., p. 69

Revista da Faculdade de Direito da UFRGS, v. 19, Marco/2001
Assim sendo, a decisão de patrimonializar ou não o próprio corpo diz respeito única e exclusivamente, desde que não atinja direitos de terceiros, ao livre arbítrio de cada um, no exercício de seu direito constitucional à autonomia. Por isso, contrariamente ao que versa o art. 11 do Projeto do novo Código Civil, o único tipo de limitação que pode ser dado a esse direito fundamental é o voluntário. Disso advém a inconstitucionalidade do dispositivo. Uma vez que o indivíduo tenha decidido pela patrimonialização de seu direito de personalidade, então pode, e deve, o Direito civil regulamentar o destino desse direito, tornado bem. o que permite, dentro da visão plural de propriedade, propor, como faz HERMITTE, no artigo citado, a construção do conceito de "bem de origem e destinação humana", que poderia ser positivamente considerado como "fora do mercado"108, mas nunca fora do comércio.

Portanto, a dignidade humana não pode, de forma alguma, ser considerada como princípio de indisponibilização do corpo humano. Muito antes pelo contrário: é garante da liberdade de disposição. A necessidade de se regular do destino do direito patrimonializado é mais uma razão pela qual a normatização da patrimonialização dos direitos de personalidade é imperiosa.

\section{CONCLUSÃO}

O princípio da dignidade da pessoa humana, não obstante sua inclusão no texto constitucional, é, tanto por sua origem quanto pela sua concretização, um instituto basilar do Direito privado. Enquanto fundamento primeiro da ordem jurídica constitucional, o é, também, do Direito público. Indo mais além, pode-se dizer que é a interface entre am-

\footnotetext{
${ }^{108}$ Para a autora, bem fora do mercado seria aquele que, estando no tráfego jurídico, não poderia ser alvo de alienação onerosa. Marie-Angèle HERMTTTE, op. cit., p. 325.
}

O seu reconhecimento, enquanto direito fundamental, leva à necessidade de requestionamento de uma série de dogmas civilísticos, em especial aqueles que constituem seu núcleo central: a autonomia, os bens, o patrimônio, a pessoa e a propriedade. Leva, tamàm, necessidade de reconstrução do conceito de direito subjetivo, tema de extrema complexidade, e que não seria possível abordar neste texto, não podendo, no entanto, deixar de ser referido.

Porém, de suas relações com a autonomia e as teorias da pessoa e da personalidade, as quais foram abordadas com maior profundidade, podese, certamente, retirar algumas conclusões:

1. Os direitos da personalidade são direitos fundamentais do indivíduo, subsumidos no princípio da dignidade da pessoa humana, em si direito fundamental, e, devendo ser alvo da tutela do Estado, são campo de livre exercício da autonomia privada, dela constitutivo, não podendo ser limitados senão tendo em vista a salvaguarda de direitos de terceiros;

2. O respeito desses limites é condição sine qua non para a existência de um Estado democrático de Direito, e salvaguarda necessária ao totalitarismo;

3. Por essas razões, não pode o Estado determinar quaisquer padrões objetivos de exercício dos direitos da dignidade, através do estabelecimento de regras morais oficiais, sob pena de, por superposição do público ao privado, em nome do bem absoluto, conduzir ao terror totalitário;

4. Pode e deve o Direito, no entanto, regular a patrimonialização dos direitos de personalidade, indispensável que é à sociedade contemporânea. 


\section{BIBLIOGRAFIA}

ALPA, Guido. Status e capacità: la costruzion giuridica delle differenze individuali. Roma: Laterza, 1993.

ALVES, Gláucia Corrêa Retamozo Barcellos. Do nominalismo ao direito moderno: uma leitura de Michel Villey. UFRGS/PPGD, Disciplina de Teoria Geral do Direito, monografia. Porto Alegre, 1999. datilografado.

AUBRY ET RAU. Cours de Droit civil français d'après la méthode de Zachariae. Paris: Marchal et Godde, 1917. tomo IX.

ÁVILA, Humberto Bergmann. $A$ distinção en tre princípios e regras e a redefinição do dever de proporcionalidade. Munique, 1999. datilografado.

BARCELLOS, Daniela Silva Fontoura de. $A$ descendência da dicotomia publicização do privado, publicização do público e a sua superação: a perspectiva de Ludwig Raiser. PPGD/UFRGS, Disciplina de Teoria Gera do Direito Privado, monografia. Porto Alegre, 1999. datilografado.

BETTI, Emilio. Storia e dogmatica del diritto. In: Diritto, Metodo, Ermeneutica: scritti scelt a cura di Giuliano Crifó. Milão: Giuffrè, 1991.

BEVILÁQUA, Clóvis. Em defeza do Projecto de Codigo Civil brazileiro. Rio de Janeiro: Francisco Alves, 1906.

. Theoria Geral do Direito Civil. atualiz. Achilles Beviláqua. Rio de Janeiro: FrancisAchilles Bevilaqua
co Alves, 1953.

CANARIS, Claus-Wilhelm. Pensamento sistemá tico e conceito de sistema na Ciência do Direito. trad. António Menezes Cordeiro. Coimbra: Fundação Calouste Gulbenkian, 1989.

CANOTILHO, J. J. Gomes. Direito Constitucional. Coimbra: Almedina, 1993.

CARVALHO, Orlando de. Les droits de l'homme dans le Droit Civil portugais. In: Boletim da Faculdade de Direito da Univer sidade de Coimbra, n. XLIX, 1973, pp. 124.

CORREA, André Rodrigues. A obrigação como totalidade e como processo. UFRGS/ PPGD, disciplina de Teoria Geral do Dire to Privado, monografia. Porto Alegre, 1997. datilografado.

CORREA DE OLIVEIRA, José Lamartine. A teoria das pessoas no Esboço de Teixeira de Freitas. Superação e permanência. In: SCHIPANI, Sandro, org. Augusto Teixeira de Freitas e il Diritto Latinoamericano. dé Freitas e il Diritto Latinoameric

CORTIANO JÚNIOR, Eroulths. Alguns apontamentos sobre os chamados direitos da personalidade. In: FACHIN, Luiz Edson. Repensando os fundamentos do Direito Civil brasileiro contemporâneo. Rio de Janeiro: Renovar, 1998, pp. 31-56.

CUNHA, Alexandre dos Santos. A autonomia privada frente à dicotomia público vs. privado: algumas reflexôes. Monografia apresentada ao PPGD/UFRGS, quando do exame de seleção para ingresso em 1999. Porto Alegre, 1998. datilografado.

A teoria das pessoas de Teixeira de Freitas entre individualismo e humanismo. In: Anais do VI Congresso Brasileiro de Filosofia. São Paulo: Instituto Brasileiro de Filosofia, no prelo; Revista da Faculdade de Direito da UFRGS, n.18. Porto Alegre: Síntese, 2000.

DWORKIN, Ronald. Taking rights seriously. Cambridge: Harvard University Press, 1978. GEDIEL, José Antônio Peres. Tecnociência, dissociação e patrimonialização jurídica do corpo humano. In: FACHIN, Luiz Edson. Repensando os fundamentos do Direito Civil brasileiro contemporâneo. Rio de Janeiro: Renovar, 1998, pp. 57-86.

GOMES, Orlando. Raízes históricas e sociológicas do Código Civil brasileiro. In: Revista da AJURIS, n. 9, 1979.

GROSSI, Paolo. La propiedad y las propiedades: un analisis histórico. trad. Angel M. López y Lopez. Madri: Civitas, 1992. HABA, Enrique P. Droits de l'homme, concepts mouvants, idéologies. In: Archives de Philosophie du Droit, n. 29, 1984, pp. 323340.

Droits de l'homme, libertés individuelles et rationalité juridique. In: Archives de Philosophie du Droit n. 25, 1980, pp. 325344.
HATTENHAUER, Hans. Conceptos fundamentales del Derecho Civil. trad. Pablo Salvador Coderch. Barcelona: Ariel, 1987. HERMITTE, Marie-Angèle. Le corps hors du commerce, hors du marché. In: Archives de Philosophie du Droit, n. 33, 1988.

HESSE, Konrad. Derecho Constitucional y Derecho Privado. trad. Ignácio Gutiérrez y Gutiérrez. Madri: Civitas, 1995

HITLER, Adolf. Minha luta. trad. não indicado. São Paulo: Moraes, 1983

HUSSON, Léon. Droits de l'homme et droits subjectifs. In: Archives de Philosophie du Droit, n. 26, 1981, pp. 345-380.

KANT, Immanuel. Métaphysique des moeurs. trad. Alain Renaut. Paris: GF-Flammarion, 1994.

LAFER, Celso. A reconstrução dos Direitos Humanos: um diálogo com o pensamento de Hannah Arendt São Paulo, Companhia das Letras, 1998.

LARENZ, Karl. Derecho Civil: parte general. trad. Miguel Izquierdo y Macías-Picavea. Madri: Editorial Revista de Derecho Privado/ EDERSA, 1978.

. Derecho justo: fundamentos de ética juridica trad. Luis Díez-Picazo. Madri: Civitas, 1993. Metodología de la Ciencia del Derecho. trad. Marcelino Rodríguez Molinero. Barcelona: Ariel, 1994.

. Rechtsperson und subjektives Recht. Zur

Wandlung der Rechtsgrundbegriffe. In: AA.VV., Grundfragen der neuen Rechtswissenchaft. Berlim: Junker und Dünnhaupt, 1934

LA TORRE, Massimo. Nostalgia for the homogeneous community: Karl Larenz and the National-socialist theory of contract. Florença: European University Institute Working Papers in Law, 1990

LOCKE, John. Two treatises of government. org Peter Laslett. Cambridge: Cambridge University Press, 1988.

MACPHERSON, C. B. A teoria política do individualismo possessivo de Hobbes a Locke. trad. Nelson Dantas. São Paulo: Paz e Terra, 1979.

MESSINETTI, Davide. Personalità (diritti della) In: Enciclopedia Giuridica Giuffrè. Milão: Giuffrè, 1984. verbete.
MOULY, Christian. La proprieté. In: CABRILLAC, Rémy et alli, orgs. Droits et libertés fondamentaux. Paris: Dalloz, 1997, pp. $475-491$

NEGREIROS, Teresa. Fundamentos para uma interpretação constitucional do princípio da boa-fé. Rio de Janeiro: Renovar, 1998.

OPPETTT, Bruno. Philosophie du Droit. Paris: Dalloz, 1999.

PAVIA, Marie-Luce. Le principe de dignité de la personne humaine: un nouveau principe constitutionnel. In: CABRILLAC, Rémy et alli, orgs. Droits et libertés fondamentaux. Paris: Dalloz, 1997, pp. 99-114.

PÉRSICO, Adriana Rodríguez. Intelectuales hoy: ni anfitriones ni turistas. In: ANTELO Raúl et alli, orgs. Declínio da arte, ascensão da cultura. Florianópolis: ABRALIC/Letras Contemporâneas, 1998

PRATA, Ana. A tutela constitucional da auto nomia privada. Coimbra: Almedina, 1982.

RAISER, Ludwig. Il compito del diritto privato. trad. Marta Graziadei. Milão: Giuffrè, 1990.

REICH, Norbert. Mercado y Derecho. trad. Antoni Font. Barcelona: Ariel, 1985.

ROUSSEAU, Dominique. Les libertés individuelles et la dignité de la personne humaine. Paris: Montchrestien, 1998.

SERPA LOPES, Miguel Maria de. Curso de Direito Civil. atualiz. José Serpa Santa Maria. Rio de Janeiro: Freitas Bastos, 1996, vol. VI

SÈVE, René. Déterminations philosophiques d'une théorie juridique: la théorie du patrimoine d'Aubry et Rau. In: Archives de Philosophie du Droit n. 24, 1979, pp. 247-258.

TEIXEIRA DE FREITAS, Augusto. Esboço. Brasilia: EdUnB/Ministério da Justiça, 1982. 2 volumes.

- . Vocabulario Juridico. Rio de Janeiro: Garnier, 1883.

VARELA, Laura Beck. Posse, conceito unitário, entre abstração e autonomia. UFRGS/ PPGD, Disciplina de Teoria Geral do Direito Privado, monografia. Porto Alegre, 1999. datilografado.

VILLEY, Michel. La genèse du droit subjectif chez Guillaume d'Occam. In: Archives de Philosophie du Droit n. 9, 1964. 